Jurnal MAKSIPRENEUR, Vol. VI, No. 1, Desember 2016, hal. 55 - 66

\title{
EVALUASI KINERJA KEUANGAN BADAN LAYANAN UMUM DAERAH KANTOR PENGELOLAAN TAMAN PINTAR YOGYAKARTA TAHUN 2011 - 2015
}

\author{
Siwi Susanti (siwi.tamanpintar@gmail.com) \\ Bambang Sugeng Dwiyanto (bsugengd@yahoo.co.id) \\ Fakultas Ekonomi Universitas Proklamasi 45
}

\begin{abstract}
This study aims to determine the financial performance of PPK-BLUDs Management Office Taman Pintar Yogyakarta from the financial aspect using financial ratios, determine the amount of revenue and expenditure performance and determine the amount of the difference between actual revenue and expenditure based financial statements from 2011-2015. Based on the results of this study concluded that the liquidity ratio is very high on the raw value / ideal, it indicates poor management performance because there are many idle funds. Judging from the solvency ratio below the standard value / ideal, so it can be interpreted either as a low solvency ratio has a smaller risk of loss. Judging from the profitability ratio is in the range of sizes of standard value / ideal, so it can be said that the excellent financial performance for the conduct management activities successfully apply the principles of efficiency and productivity. Judging from the achievement of revenue may exceed the planned target indicating that a management plan to be realized with both revenue targets. seen from the achievements of financing showed a good performance, because the management in making budget planning in accordance with the needs, and based on the principles of efficiency and productivity. Judging from the cost recovery rate showed a good performance, because it can cover its costs (cost) income earned (revenue).
\end{abstract}

Keywords: financial ratios, income accomplishment, achievement funding and cost recovery rate.

\section{PENDAHULUAN}

Semenjak ditetapkannya Kantor Pengelolaan Taman Pintar sebagai Badan Layanan Umum Daerah (BLUD) dengan status penuh (22 Oktober 2010) belum pernah melakukan evaluasi pengelolaan keuangan, dan mengingat Taman Pintar merupakan institusi yang padat modal dengan biaya pelayanan yang cenderung meningkat maka evaluasi kinerja keuangan perlu dilakukan sehingga dapat diketahui kinerja dari aspek keuangan dan dapat diketahui capaian realisasi pendapatan dan pembiayaan dengan hasil yang diharapkan, serta dapat menganalisa terjadinya penyimpangan dari rencana yang ditetapkan diawal, karena kinerja merupakan gambaran mengenai tingkat pencapaian pelaksanaan suatu kegiatan/program/kebijakan dalam mewujudkan sasaran, tujuan, misi dan visi organisasi yang tertuang dalam strategic planing suatu organisasi.

Apalagi pada Pola Pengelolaan Keuangan BLUD (PPK-BLUD) adalah pola pengelolaan keuangan yang memberikan fleksibilitas berupa keleluasaan untuk 
menerapkan praktek-praktek bisnis yang sehat untuk meningkatkan pelayanan kepada masyarakat, sebagai pengecualian dari ketentuan pengelolaan keuangan daerah pada umumnya.

Penelitian ini dimaksudkan untuk mengetahui nilai kemampuan kinerja keuangan PPK-BLUD Taman Pintar dari aspek keuangan dengan menggunakan rasio keuangan, besaran pendapatan dan belanja yang diperkirakan dengan pendapatan dan belanja riil pada tiap revenue center PPK-BLUD Taman Pintar dan besaran selisih antara realisasi pendapatan dan belanja dibandingkan dengan target pendapatan dan belanja, beserta penyebabnya Evaluasi Kinerja BLUD Kantor PengelolaanTaman Pintar tahun 2011 2015.

\section{TINJAUAN PUSTAKA}

1. BLUD

BLUD Kantor PengelolaanTaman Pintar (KPTP) adalah Satuan Kerja Perangkat Daerah (SKPD) di lingkungan pemerintah Kota Yogyakarta yang dibentuk untuk memberikan pelayanan kepada masyarakat berupa penyediaan barang dan/atau jasa yang dijual tanpa mengutamakan mencari keuntungan, dan dalam melakukan kegiatannya didasarkan pada prinsip efisiensi dan produktifitas.

Pola Pengelolaan Keuangan BLUD (PPK-BLUD) adalah pola pengelolaan keuangan yang memberikan fleksibilitas berupa keleluasaan untuk menerapkan praktek-praktek bisnis yang sehat untuk meningkatkan pelayanan kepada masyarakat, sebagai pengecualian dari ketentuan pengelolaan keuangan daerah pada umumnya.

\section{KINERJA KEUANGAN}

Menurut Mahsun (2006) dalam bukunya Pengukuran Kinerja Sektor Pulbik menyatakan bahwa kinerja adalah gambaran mengenai tingkat pencapaian pelaksanaan suatu kegiatan/program/kebijakan dalam mewujudkan sasaran, tujuan, misi dan visi organisasi yang tertuang dalam strategic planing suatu organisasi. Sedangkan menurut Permendagri, kinerja keuangan adalah tingkat kemampuan pendapatan dari layanan yang cenderung meningkat dan efisien dalam membiayai pengeluaran. Sehingga dapat disimpulkan Kinerja keuangan merupakan gambaran tingkat pencapaian pelaksanaan suatu kegiatan/program/kebijakan sesuai dengan kemampuan pendapatan dari layanan yang tertuang dalam strategic planing suatu organisasi berdasarkan pada prinsip efisiensi dan produktivitas.

\section{LAPORAN KEUANGAN}

Prastowo, Juliati (2002) menyatakan bahwa laporan keuangan disusun dengan tujuan untuk informasi yang menyangkut posisi keuangan, kinerja dan perubahan posisi keuangan suatu perusahaan yang bermanfaat bagi sejumlah besar pemakai dalam pengambilan keputusan ekonomi.

\section{EVALUASI DAN PENILAIAN KINERJA}

Evaluasi bertujuan untuk mengukur tingkat pencapaian hasil pengelolaan BLUD sebagaimana ditetapkan dalam Rencana Strategi (Renstra) Bisnis dan Rencana Bisnis dan Anggaran (RBA).

Renstra Bisnis BLUD adalah dokumen lima tahunan yang memuat visi, misi, program strategis, pengukuran pencapaian kinerja dan arah kebijakan operasional BLUD. 
Renstra Bisnis BLUD dipergunakan sebagai dasar penyusunan RBA dan evaluasi kinerja. RBA BLUD adalah dokumen perencanaan bisnis dan pengangaran tahunan yang berisi program, kegiatan, target kinerja dan anggaran BLUD.

Evaluasi dan penilaian kinerja dari aspek keuangan menurut Permendagri Nomor 61 Tahun 2007 Pasal 128 dapat diukur berdasarkan tingkat kemampuan BLUD dalam :

1. Memperoleh hasil usaha atau hasil kerja dari layanan yang diberikan (rentabilitas)

2. Memenuhi kewajiban jangka pendeknya (likuiditas)

3. Memenuhi seluruh kewajibannya (solvabilitas)

4. Kemampuan penerimaan dari jasa layanan untuk membiayai pengeluaran.

\section{KERANGKA PIKIR}

Berdasar uraian di depan dapat dijelaskan kerangka pikir dalam penelitian ini sebagai berikut:

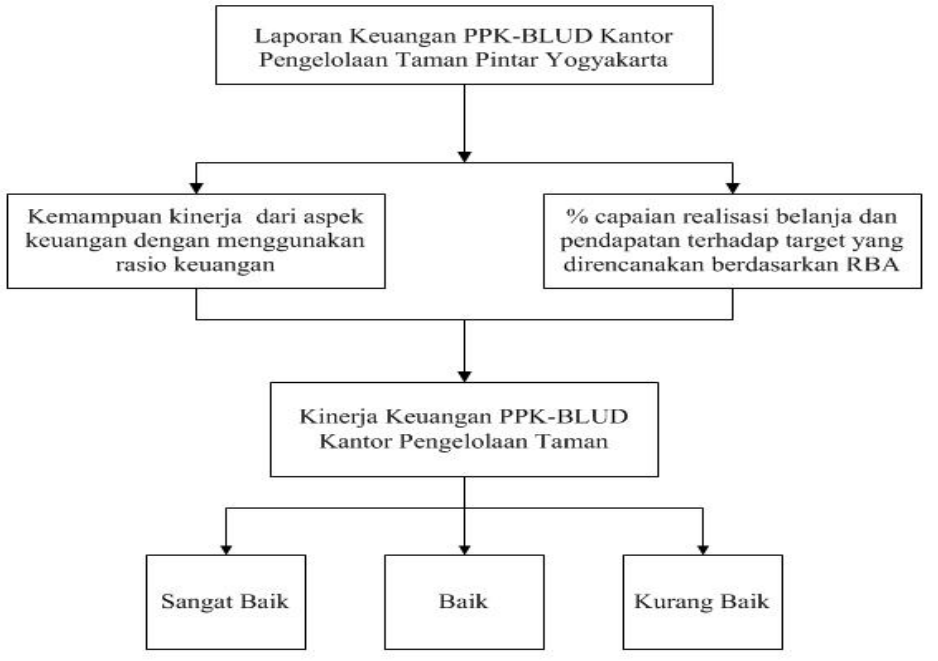

\section{METODE PENELITIAN}

Penelitian dilakukan di Kantor Pengelolaan Taman Pintar Yogyakarta dengan obyek data laporan keuangan BLUD Kantor Pengelolaan Taman Pintar tahun 2011 - 2015 yang terdiri dari Neraca dan Laporan Realisasi Anggaran/Laporan Opearasional.

Metode analisis data yang digunakan dalam penelitian ini adalah analisis kualitatif dan analisis kuantitatif sebagai berikut:

1. Mengolah data keuangan Kantor Pengelolaan Taman Pintar dengan menerapkan analisis rasio keuangan, menghitung capaian pendapatan dan capaian pembiayaan.

2. Membandingkan hasil analisis data kuantitatif dengan ukuran nilai baku untuk mendapatkan penilaian kualitatif dari kinerja keuangan.

Adapun analisis rasio keuangan yang digunakan terdiri dari:

1. Rasio Likuiditas

Kasmir (2010), menyebutkan bahwa rasio likuiditas merupakan rasio yang menggambarkan kemampuan perusahaan dalam memenuhi kewajiban (utang) jangka 
pendek. Jenis-jenis rasio likuiditas menurut Kasmir (2010) yang digunakan terdiri dari:

\subsection{Current Ratio}

Current ratio merupakan perbandingan antara aktiva lancar dan kewajiban lancar dan merupakan ukuran yang paling umum digunakan untuk mengetahui kesanggupan suatu perusahaan memenuhi kewajiban jangka pendeknya. Current ratio dapat dihitung dengan equiation model sebagai berikut:

$$
\text { Current Ratio }=\frac{\text { Aktiva Lancar }}{\text { Hutang Lancar }}
$$

Ukuran baku current ratio sebesar 1.75 - 2.75 (Syaaf, A.C., 2000 dalam Hartati, 2012),(Masyhuda,2013).

\subsection{Quick Ratio}

Merupakan rasio yang menunjukkan kemampuan perusahaan memenuhi atau membayar kewajiban atau utang lancar (utang jangka pendek) dengan aktiva lancar tanpa memperhitungkan nilai persediaan (inventory). Dapat dihitung dengan equation model sebagai berikut:

$$
\text { Quick Ratio }=\frac{\text { AktivaLancar-Persediaan }}{\text { HutangLancar }}
$$

Ukuran baku quick ratio sebesar 1.50 - 2.50 (Masyhuda,2013).

\subsection{Cash Ratio}

Rasio ini merupakan rasio yang menunjukkan posisi kas yang dapat menutupi hutang lancar dengan kata lain cash ratio merupakan rasio yang menggambarkan kemampuan kas yang dimiliki dalam manajemen kewajiban lancar tahun yang bersangkutan. Dapat dihitung dengan equation model sebagai berikut:

$$
\text { Cash Ratio }=\frac{\text { Kas }+ \text { Bank }}{\text { Hutang Lanczr }}
$$

Ukuran baku cash ratio sebesar 0.15 - 0.20 (Masyhuda, 2013).

\subsection{Rasio Solvabilitas}

Rasio solvabilitas, merupakan rasio yang digunakan untuk mengukur sejauh mana aktiva perusahaan dibiayai dengan utang (Kasmir, 2010). Rasio solvabilitas yang digunakan dalam penelitian ini adalah Debt to Total Assets Ratio (DAR). Suatu perusahaan dikatakan solvabel berarti perusahaan tersebut memiliki aktiva dan kekayaan yang cukup untuk membayar hutang-hutangnya. Dapat dihitung dengan equation model sebagai berikut:

$$
\text { Debt to Total Assets Ratio }=\frac{\text { Total Hutang }}{\text { Total Aktiva }}
$$

Ukuran baku Debt to Total Assets Ratio sebesar $\leq 0.45$ ( Masyhuda,2013). 


\subsection{Rasio Rentabilitas}

Rentabilitas adalah kemampuan perusahaan menghasilkan laba selama periode tertentu (Munawir, 2010). Dengan demikian rentabilitas suatu perusahaan dapat diketahui dengan memperbandingkan antara laba yang diperoleh dalam suatu periode dengan jumlah aset perusahaan tersebut. Rasio rentabilitas yang digunakan dalam penelitian ini adalah Return on Assets (ROA). Dapat dihitung dengan equation model sebagai berikut:

$$
\text { Return on Assets }=\frac{\text { Laba/Surplus }}{\text { Total Aset }}
$$

Ukuran baku Return on Assets sebesar 0.025 - 0.15 (Syaaf, A.C., 2000 dalam Hartati,2012),( Masyhuda,2013)

\subsection{Capaian pendapatan}

Capaian pendapatan menunjukkan hubungan antara realisasi pendapatan dengan target pendapatan berdasarkan RBA BLUD. Rasio ini digunakan untuk mengukur seberapa jauh pencapaian target pendapatan (revenue center) BLUD. Dapat dihitung dengan dengan equation model sebagi berikut:

$$
\text { Capaian pendapatan }=\frac{\text { Realisasi Pendapatan }}{\text { Targot Pondapatan }} \times 100 \%
$$

1.7 Capaian pembiayaan

Capaian pembiayaan menunjukkan hubungan atara realisasi pembiayaan dengan target pembiayaan. Rasio ini digunakan untuk mengukur seberapa jauh pencapaian target pembiayaan (cost center) BLUD. Dapat dihitung dengan equation model sebagai berikut:

$$
\text { Capaian pembiayaan }=\frac{\text { Realisasi Pembiayaan }}{\text { Target Pembiayaan }} \times 100 \%
$$

Indikator kinerja sasaran Pemerintah Kota Yogyakarta menggunakan skala nilai peringkat kinerja yang mengacu pada formulir Tabel VII-C dalam Peraturan Mentri Dalam Negri Nomor 54 Tahun 2010, termasuk dalam menilai capaian pendapatan dan capaian pembiayaan.

Tabel 1 Skala Nilai Peringkat Kinerja

\begin{tabular}{|c|c|c|}
\hline No & Interval Nilai Kinerja & Kriteria Penilaian Realisasi Kinerja \\
\hline 1 & $91 \% \geq$ & Sangat Tinggi \\
\hline 2 & $76 \% \leq 90 \%$ & Tinggi \\
\hline 3 & $66 \% \leq 75 \%$ & Sedang \\
\hline 4 & $51 \% \leq 65 \%$ & Rendah \\
\hline 5 & $\leq 50 \%$ & Sangat Rendah \\
\hline
\end{tabular}

Sumber: Permendagri 54 Tahun 2010

\subsection{Cost Recovery Rate}

Cost Recovery Rate adalah nilai yang menunjukkan seberapa besar kemampuan suatu badan usaha menutup biayanya (Cost) dibandingkan dengan penghasilan 
yang didapatkan (revenue). Dapat dihitung dengan equation model sebagai berikut:

$$
\text { Cost Recovery Rate }=\frac{\text { Seluruh } P \text { er.dapatan }}{\text { Total Biaya }}
$$

Ukuran nilai ideal Cost Recovery Rate adalah > 1 (Hartati, 2012).

\section{HASIL PENELITIAN DAN PEMBAHASAN}

1. Rasio Likuiditas

Tabel 2. Rasio Likuiditas

BLUD Kantor Pengelolaan Taman Pintar

\begin{tabular}{|c|l|r|r|r|r|r|r|c|}
\hline \multirow{2}{*}{ No } & \multicolumn{1}{|c|}{ Rasio } & \multicolumn{5}{|c|}{ TAHUN } & $\begin{array}{c}\text { Ukuran } \\
\text { Baku/Ideal }\end{array}$ & $\begin{array}{c}\text { Kinerja } \\
\text { Keuangan }\end{array}$ \\
\cline { 3 - 7 } & 2011 & 2012 & 2013 & 2014 & 2015 & \\
\hline & $\begin{array}{l}\text { Current } \\
\text { Ratio }\end{array}$ & 26.32 & 22.74 & 15.14 & 23.98 & 10.11 & $1.75-2.75$ & Kurang Baik \\
\hline 2 & Quick Ratio & 22.80 & 19.05 & 11.13 & 19.79 & 8.45 & $1.50-2.50$ & Kurang Baik \\
\hline 3 & Cash Ratio & 19.01 & 16.69 & 10.13 & 18.79 & 8.17 & $0.15-0.20$ & Kurang Baik \\
\hline
\end{tabular}

Sumber: Hasil Perhitungan Rasio Likuiditas BLUD Kantor Pengelolaan Taman Pintar

\section{a. Current Ratio}

Pada tahun 2011 diperoleh current ratio (rasio aktiva lancar) terhadap hutang lancar sebesar 26.32, yang artinya jumlah aset lancar sebanyak 26.32 kali kewajiban jangka pendek atau setiap $\mathrm{Rp} \mathrm{1,-} \mathrm{kewajiban} \mathrm{dijamin} \mathrm{oleh} \mathrm{Rp} 26.32$ aktiva lancar. Sedangkan rasio aktiva lancar tahun 2012 sebesar 22.74, tahun 2013 sebesar 15.14, tahun 2014 sebesar 23.98 dan tahun 2015 sebesar 10.11. Rata-rata dari current ratio BLUD Kantor Pengelolaan Taman Pintar selama lima periode sebesar 19.66, di atas nilai baku/ideal (1.75-2.75).

\section{b. Quick Ratio}

Pada tahun 2011 diperoleh rasio paling likuid terhadap hutang lancar sebesar 22.80, yang artinya jumlah aktiva paling likuid sebanyak 22.80 kali kewajiban jangka pendek atau setiap Rp 1,- kewajiban dijamin oleh rp 22.80 aktiva paling likuid. Pada tahun 2012 diperoleh rasio sebesar 19.04, tahun 2013 diperoleh rasio sebesar 11.12, tahun 2014 diperoleh rasio sebesar 19.78, dan pada tahun 2015 diperoleh rasio sebesar 8.45. Rata-rata quick ratio BLUD Kantor Pengelolaan Taman Pintar selama lima periode sebesar 16.24, di atas nilai baku/Ideal (1.50-2.50).

\section{c. Cash Ratio}

Hasil perhitungan tahun 2011 diperoleh cash rasio sebesar 19.01 yang artinya jumlah uang kas yang tersedia sebesar 19.01 kali kewajiban jangka pendek atau setiap Rp 1,kewajiban dijamin oleh uang kas yang tersedia Rp 19.01,-. Pada tahun 2012 diperoleh rasio sebesar 16.69, tahun 2013 diperoleh rasio sebesar 10.12, tahun 2014 diperoleh rasio sebesar 18.79, dan pada tahun 2015 diperoleh rasio sebesar 8.17. Rata-rata dari cash ratio BLUD Kantor Pengelolaan Taman Pintar selama lima periode sebesar 14.55 di atas nilai baku/ideal (0.15-0.20). 
Tabel 3. Rasio Solvabilitas

BLUD Kantor Pengelolaan Taman Pintar

\begin{tabular}{|c|c|c|c|c|c|c|c|c|}
\hline \multirow{2}{*}{ No } & \multirow{2}{*}{ Rasio } & \multicolumn{5}{|c|}{ Tahun } & \multirow{2}{*}{$\begin{array}{c}\text { Ukuran } \\
\text { Baku/Idea } \\
1\end{array}$} & \multirow{2}{*}{$\begin{array}{c}\text { Kinerja } \\
\text { Keuanga } \\
n\end{array}$} \\
\hline & & 2011 & 2012 & 2013 & 2014 & 2015 & & \\
\hline 1 & $\begin{array}{l}\text { Debt to } \\
\text { Assets Ratio }\end{array}$ & $\begin{array}{c}0.002 \\
2\end{array}$ & $\begin{array}{c}0.003 \\
2\end{array}$ & $\begin{array}{c}0.003 \\
4\end{array}$ & $\begin{array}{c}0.002 \\
6\end{array}$ & $\begin{array}{c}0.009 \\
5\end{array}$ & $\leq 0.45$ & Baik \\
\hline
\end{tabular}

Sumber: Hasil Perhitungan Rasio Solvabiltas BLUD Kantor Pengelolaan Taman Pintar

Debt to Assets Ratio BLUD Kantor Pengelolaan Taman Pintar pada tahun 2011 sebesar 0.0022 , artinya bahwa pada tahun 2011 prosentase aktiva yang dibiayai oleh utang sebesar $0.22 \%$, tahun 2012 sebesar $0.32 \%$, tahun 2013 sebesar $0.34 \%$, tahun 2014 sebesar $0.26 \%$ dan 2015 sebesar $0.95 \%$. Sedangkan rata-rata debt to total assets ratio selama lima periode sebesar 0.0042 atau sebesar $0.42 \%$, dibawah nilai baku/ideal $(\leq 0.45)$.

3. Rasio Rentabilitas

Tabel 4. Rasio Rentabilitas

BLUD Kantor Pengelolaan Taman Pintar

\begin{tabular}{|c|c|c|c|c|c|c|c|c|}
\hline \multirow{2}{*}{ No } & \multirow{2}{*}{ Rasio } & \multicolumn{5}{|c|}{ Tahun } & \multirow{2}{*}{$\begin{array}{c}\text { Ukuran } \\
\text { Baku/Ideal }\end{array}$} & \multirow{2}{*}{$\begin{array}{c}\text { Kinerja } \\
\text { Keuangan }\end{array}$} \\
\hline & & 2011 & 2012 & 2013 & 2014 & 2015 & & \\
\hline 1 & $\begin{array}{l}\text { Return on } \\
\text { Assets }\end{array}$ & 0.038 & 0.046 & 0.031 & 0.047 & 0.072 & $\begin{array}{c}0.025- \\
0.15 \\
\end{array}$ & Sangat Baik \\
\hline
\end{tabular}

Sumber: Hasil Perhitungan Rasio Rentabilitas BLUD Kantor Pengelolaan Taman Pintar

Dari hasil perhitungan di atas dapat diketahui return on assets pada tahun 2011 diperoleh rasio 0.038 atau sebesar 3.8\%, tahun 2012 diperoleh rasio 0.046 atau sebesar 4.6\%, tahun 2013 doperoleh rasio 0.031 atau sebesar 3.1\%, tahun 2014 diperoleh rasio 0.047 atau sebesar $4.7 \%$, dan pada tahun 2015 diperoleh rasio 0.072 atau sebesar $7.2 \%$. Sedangkan rata-rata return on assets BLUD Kantor Pengelolaan Taman Pintar selama lima periode sebesar 0.047, ukuran baku/ideal (0.025-0.15).

4. Capaian Target Pendapatan

Tabel 5. Capaian Target Pendapatan BLUD Kantor Pengelolaan Taman Pintar

\begin{tabular}{|c|c|c|c|c|c|}
\hline KOMPONEN & 2011 & 2012 & 2013 & 2014 & 2015 \\
\hline PENDAPATAN BLUD & & & & & \\
\hline 1. Pendapatan dari Jasa Layanan & $107.3 \%$ & $107.6 \%$ & $110.9 \%$ & $101.3 \%$ & $99.8 \%$ \\
\hline 2. Hibah & & & & $100.0 \%$ & \\
\hline 3. Hasil Kerjasama & $114.7 \%$ & $99.0 \%$ & $102.2 \%$ & $131.0 \%$ & $119.0 \%$ \\
\hline 4. $\mathrm{APBD}$ & $97.6 \%$ & $94.0 \%$ & $92.7 \%$ & $73.1 \%$ & $87.3 \%$ \\
\hline 5. $\mathrm{APBN}$ & & & & & \\
\hline 6. Lain-lain Pendapatan BLUD yang sah & $293.7 \%$ & $382.1 \%$ & $167.0 \%$ & $132.9 \%$ & $134.6 \%$ \\
\hline CAPAIAN TARGET PENDAPATAN & $110.1 \%$ & $108.8 \%$ & $109.7 \%$ & $102.1 \%$ & $101.8 \%$ \\
\hline
\end{tabular}

Sumber: BLUD Kantor Pengelolaan Taman Pintar 
Berdasarkan hasil perhitungan pada Tabel 5 di atas dapat diketahui bahwa selama 5 periode Capaian Target Pendapatan BLUD Kantor Pengelolaan Taman Pintar dapat melampaui target pendapatan yang direncanakan (100\%).

a. Pendapatan Jasa Layanan

Pendapatan Jasa Layanan pada tahun 2011-2014 meningkat dikarenakan meningkatnya pengunjung pada saat liburan sekolah, libur lebaran dan libur natal. Tetapi pada tahun 2015 terjadi penurunan pengunjung dikarenakan adanya penataan area parkir wisatawan Yogyakarta dan dijadikannya Alun-alun Utara menjadi kawasan bebas parkir.

b. Pendapatan Hasil Kerjasama

Pendapatan Hasil Kerjasama pada tahun 2011, 2013,2014 \& 2015 melampaui target dikarenakan pemanfaatan space kosong di area foodcourd (2011), meningkatnya pendapatan sewa terutaman stand selling, meningkatnya event,meningkatnya pendapatan profit sharing 4D. Pada tahun 2012 pendapatan hasil kerjasama tidak tercapai dikarenakan kurangnya kesadaran penyewa dalam memenuhi kewajibannya melakukan pembayaran sewa sesuai tatakala dalam perjanjian kerjasama.

c. Pendapatan APBD

Pendapatan APBD dianggarkan untuk belanja gaji PNS BLUD yang dikelola langsung oleh PEMKOT baik dlm perencanaan maupun realisasi pendapat APBD.

d. Lain-lain Pendapatan BLUD yang sah

Lain-lain Pendapatan BLUD yang sah selama 5 periode melampaui target dikarenakan adanya animo masyarakat yang baik terhadap layanan keprograman, adanya aktivitas deposito, tahun 2011 adanya pendapatan denda keterlambatan pekerjaan pd tahun 2010, adanya pendapatan hadiah sbg juara lomba wisata berwawasan lingkungan tingkat propinsi pada tahun 2012.

5. Capaian Pembiayaan

Tabel 6. Capaian Target Pembiayaan

BLUD Kantor Pengelolaan Taman Pintar

Tahun $2011 \mathrm{~s} / \mathrm{d}$ Tahun 2015

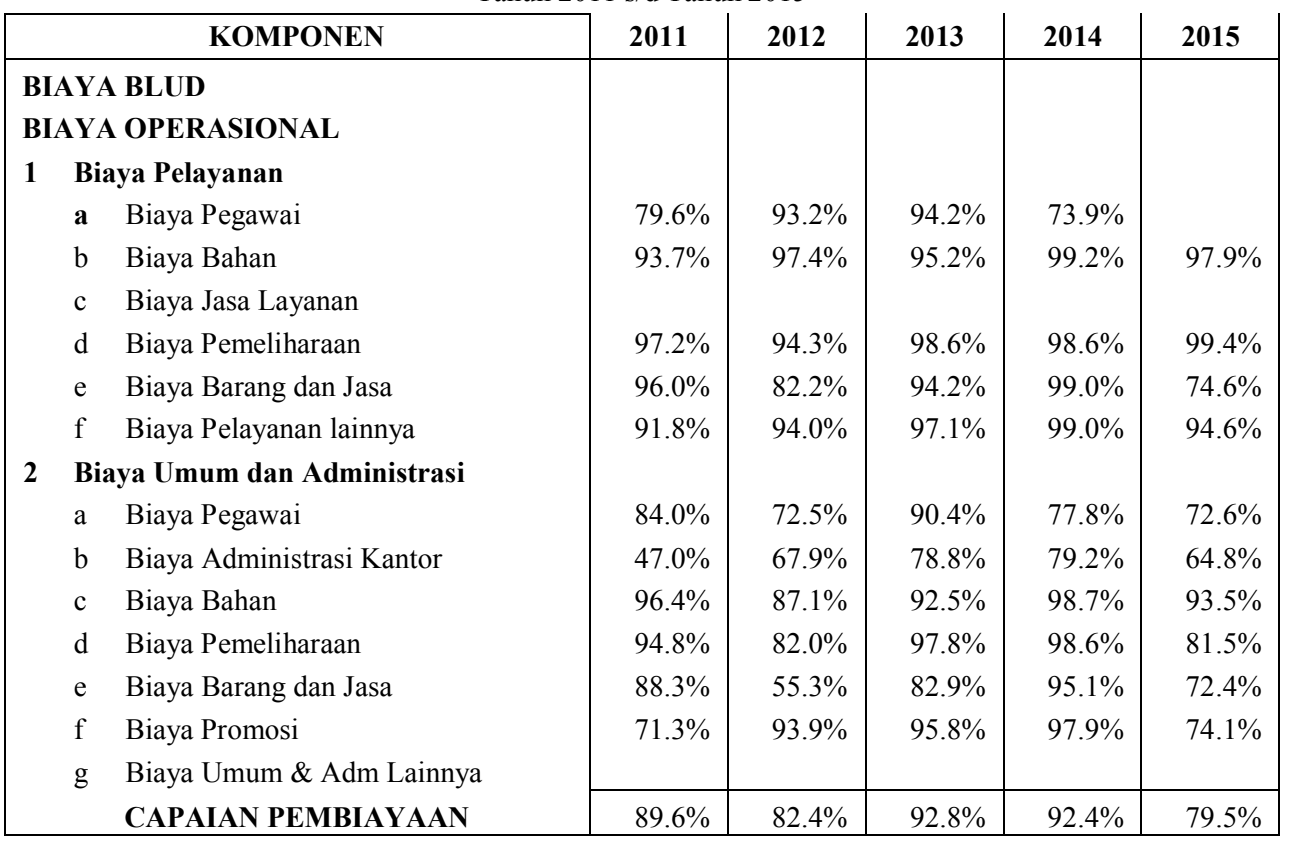


Sumber: BLUD Kantor Pengelolaan Taman Pintar

Berdasarkan hasil perhitungan capaian pembiayaan pada tabel 6. di atas diketahui bahwa selama 5 periode BLUD Kantor Pengelolaan Taman Pintar capaian realisasi lebih kecil dari target keluaran yang direncanakan (100\%). Rata-rata capaian pembiayaan BLUD Kantor Pengelolaan Taman Pintar selama lima periode sebesar 87.3\% terdapat efisiensi $12.7 \%$ sehingga dapat dikatakan penilaian realisasi capaian pembiayaan tinggi,meskipun ada beberapa pembiayaan yang serapannnya kurang dari $75 \%$ yaitu:

1) Biaya Pelayanan

a. Biaya Pegawai

Tahun 2014 capaian sebesar $73.9 \%$ dikarenakan adanya pengurangan tenaga teknis pemandu.

b. Biaya Barang dan Jasa

Tahun 2015 capaian sebesar $74.6 \%$, dikarenakan belanja listrik dianggarkan terlalu besar dikarenakan adanya pengumuman ttg keaikan TDL.

2) Biaya Umum dan Administrasi

a. Biaya Pegawai

Tahun 2012 capaian sebesar $72.9 \%$ dikarenakan adanya perubahan perwal pegawai tentang honorarium tim pengadaan barang dan jasa. Tahun 2015 capaian sebesar $72.6 \%$ dikarenakan adanya usulan kenaikan remunerasi tetapi prosentase kenaikan yang disetujui oleh PEMKOT tidak sebesar yg diusulkan.

b. Biaya Administrasi Kantor

Tahun 2011 capaian sebesar 47.0\%, Tahun 2012 capaian sebesar 67.9\%, Tahun 2015 capaian sebesar $64.8 \%$, dikarenakan tagihan telepon, air internet, belanja paket/pengiriman menyesuaian kebutuhan dan tagihan.

c. Biaya Barang dan Jasa

Tahun 2012 capaian sebesar 55.3\%, dikarenakan adanya pembatalan acara peresmian gedung Planetarium. Tahun 2015 capaian sebesar $72.4 \%$, dikarenakan ditundanya perencanaan perekrutan tenaga teknis.

d. Biaya Promosi

Tahun 2011 capaian sebesar 71.3\% dikarenakan belum merencanakan belanja jasa media masa, dokumentasi dan publikasi hanya mencakup biaya perjalanan dinas dalam daerah maupun luar daerah sehingga realisasi menyesuaikan kebutuhan. Tahun 2015 caian sebesar $74.1 \%$ dikarenakan biaya ASPAC di Manila, Philipina sudah dianggarkan oleh panitia ASPAC Conferences.

3. Cost Recovery Rate

Tabel 7. Cost Recovery Rate

BLUD Kantor Pengelolaan Taman Pintar

Tahun $2011 \mathrm{~s} / \mathrm{d} 2015$

\begin{tabular}{|c|c|c|c|c|c|c|c|}
\hline \multirow{2}{*}{ No } & \multirow{2}{*}{ Rasio } & \multicolumn{5}{|c|}{ Tahun } & \multirow{2}{*}{$\begin{array}{l}\text { nilai } \\
\text { ideal }\end{array}$} \\
\hline & & 2011 & 2012 & 2013 & 2014 & 2015 & \\
\hline 1 & $\begin{array}{l}\text { Cost Recovery } \\
\text { Rate }\end{array}$ & 1.056 & 1.065 & 0.927 & 1.105 & 1.019 & $>1$ \\
\hline
\end{tabular}

Sumber: BLUD Kantor Pengelolaan Taman Pintar

Dari hasil perhitungan selama lima periode dapat diketahui cost recovery rate BLUD Kantor Pengelolaan Taman Pintar pada tahun 2011 diperoleh nilai sebesar 1.056, menunjukkan kemampuan untuk menutup biayanya dengan penghasilan yang didapatkan 
sebesar 105.6\%, tahun 2012 sebesar 1.065, tahun 2013 sebesar 0.927 , tahun 2014 sebesar 1.105, dan tahun 2015 sebesar 1.019. Rata-rata cost recovery rate BLUD Kantor Pengelolaan Taman Pintar selama lima periode sebesar 1.034 berada di atas nilai baku ( $>1)$.

\section{KESIMPULAN DAN SARAN}

1. Kesimpulan

a. Kinerja Keuangan PPK-BLUD Kantor Pengelolaan Taman Pintar dari aspek keuangan selama lima peroide dilihat dari rata-rata rasio likuiditas secara manajemen menunjukkan kinerja kurang baik dikarenakan adanya dana yang menganggur. Dilihat dari rata-rata rasio solvabilitas menunjukkan kinerja yang baik karena memiliki aktiva yang cukup untuk membayar kewajibankewajibannya. Dilihat dari rata-rata rasio rentabilitas menunjukkan kinerja yang sangat baik karena managemen berhasil menerapkan prinsip efisiensi dan produktifitas sehingga terdapat Sisa Lebih Perhitungan Anggaran (SiLPA) serta menunjukkan posisi perusahaan semakin baik dari segi penggunaan aktiva. Sedangkan dilihat dari rata-rata cost recovery rate menunjukkan kinerja yang baik, meskipun cost recovery rate tahun 2013 sebesar 0.927 atau dibawah nilai baku/ideal.

b. Capaian pendapatan PPK-BLUD Kantor Pengelolaan Taman Pintar selama lima periode melampaui target yang direncanakan sehingga menunjukkan bahwa perencanaan managemen terhadap target pendapatan terealisasi dengan baik. Meskipun terdapat beberapa revenue center yang belum mencapai target yang diharapkan. Sedangkan rata-rata capaian pembiayaan selama lima periode termasuk tinggi dan menunjukkan kinerja yang baik, hal ini mempunyai arti bahwa manajemen dalam membuat perencanaan anggaran sesuai dengan kebutuhan, serta terlaksananya kegiatan yang didasarkan pada prinsip efisiensi dan produktifitas.

c. Rata-rata capaian pendapatan selama lima periode sebesar $106,5 \%$ atau $6,5 \%$ lebih besar dari target pendapatan yang direncanakan, dikarenakan meningkatnya pengunjung saat liburan sekolah, meningkatnya pendapatan hasil kerjasama berupa sewa dan event pada saat peak seasion dan meningkatnya pendapatan lainlain BLUD yang sah selama lima periode dikarenakan animo masyarakat yang baik terhadap layanan keprograman, adanya aktivitas jasa giro dan deposito.

d. Rata-rata capaian pembiayaan selama lima periode sebesar $87.3 \%$ terdapat efisiensi $12.7 \%$ hal ini dikarenakan realisasi Biaya Operasional BLUD Kantor Pengelolaan Taman Pintar berdasarkan prinsip efisiensi dan produktifitas.

2. Saran

a. BLUD Kantor Pengelolaan Taman Pintar memiliki rasio likuiditas yang sangat tinggi maka salah satu cara utuk menurunkan rasio likuiditas yaitu dengan mengurangi aktiva lancar tertentu untuk menambah aktiva tetap, misalkan dengan pengembangan/refresh wahana, inovasi alat-alat peraga yang up to date dan pembangunan sarana dan prasarana yang modern agar tetap memiliki daya tarik dan menambah jumlah pengunjung wisata ke Taman pintar di tengah-tengah 
persaingan wisata khususnya di wilayah Daerah Istimewa Yogyakarta dan umumnya diseluruh wilayah nusantara.

b. Dengan adanya kebijakan anggaran berimbang dan adanya penggunaan SiLPA di tahun berikutnya, maka dalam menyusun anggaran diharapkan menejemen dapat memanfaatkan SiLPA secara bijaksana, sesuai dengan perencanaan yang tepat dalam mengoptimalkan pelayanan dan melaksanakan kegiatannya berdasarkan pada prisip efisiensi dan produktifitas, sehingga diharapakan rentabilitas tetap baik dan terjaga.

\section{DAFTAR PUSTAKA}

Dokumen Laporan Keuangan Badan Layanan Umum Daerah Kantor Pengelolaan Taman Pintar Tahun 2011-2015.

Dokumen Laporan Kinerja Instansi Pemerintah Kota Yogyakarta Tahun 2014.

Dokumen Rencana Bisnis dan Anggaran Badan Layanan Umum Daerah Kantor Pengelolaan Taman Pintar Tahun 2011-2015.

Dokumen Rencana Strategi Bisnis Badan Layanan Umum Daerah Kantor Pengelolaan Taman Pintar Yogyakarta Tahun 2010.

Hartati, 2012. Pengukuran Kinerja RSUD DR. Moewardi Surakarta Dengan Menggunakan Metode Balanced Scorecard.

I.Masyhuda, 2013. Analisis Kinerja Keuangan RS PKU Muhamadiyah Yogyakarta Berdasarkan Analisis Rasio Keuangan.

Kasmir. 2010. Analisis Laporan Keuangan. Jakarta: Rajawali Pers.

Keputusan Walikota Yogyakarta Nomor 306/KEP/2010 tentang Penetapan Penerapan Pola Pengelolaan Keuangan Badan Layanan Umum Daerah (PPK-BLUD) dengan Status Penuh Pada Kantor Pengelolaan Taman Pintar Kota Yogyakarta.

Laporan Kinerja Instansi Pemerintah Kota Yogyakarta Tahun 2014.

Mahsun (2006) .Pengukuran Kinerja Sektor Publik, Edisi Pertama. Yogyakarta: BPFE, Yogyakarta.

Munawir. 2010. Analisis Laporan Keuangan. Edisi 4. Yogyakarta: Liberty.

Peraturan Pemerintah Nomor 23 Tahun 2005 tentang Pengelolaan Badan Layanan Umum.

Peraturan Mentri Dalam Negri Nomor 61 Tahun 2007 tentang Pedoman Teknik Pengelolaan Keuangan Badan Layanan Umum Daerah. 
Peraturan Menteri Dalam Negeri No. 54/2010 tentang Pelaksanaan Peraturan Pemerintah Nomor 8 Tahun 2008 tentang Tahapan, Tatacara Penyusunan, Pengendalian dan Evaluasi Pelaksanaan Rencana Pembangunan. Jakarta: Direktur jenderal Bina Pembangunan Deerah.

Peraturan Pemerintah Nomor 71 Tahun 2010 tentang Standar Akuntansi Pemerintahan.

Prastowo,Dwi dan Rifka Julianti. 2002, Analisis Laporan Keuangan (Konsep dan Aplikasi), Edisi Revisi, Yogyakarta; YKPN 


\section{TENTANG PENULIS}

Drs. Bambang Sugeng Dwiyanto, M.M.

Penulis lahir di Purworejo 2 April 1961 sebagai dosen tetap di Fakultas Ekonomi Universitas Proklamasi 45 Yogyakarta. Sebagai peneliti beliau telah mempublikasikan tulisan di berbagai jurnal. Beliau saat ini menjabat sebagai Kepala KPM (Kantor Penjaminan Mutu) di Universitas Proklamasi 45 Yogyakarta. Bidang kajian yang ditekuni adalah Manajemen Keuangan, Manajemen Operasional, dan Sosial Ekonomi.

\section{Dr. Bening Hadilinatih, M.Si.}

Penulis kelahiran Surakarta, 13 Januari 1965 menyelesaikan studi S1 pada jurusan Administrasi Negara di Universitas Diponegoro Semarang, dan S2 pada program studi Administrasi Negara Universitas Gadjah Mada Yogyakarta serta saat ini sedang menyelesaikan S3 dengan konsentrasi Manajemen Kebijakan Publik di Universitas Gadjah Mada Yogyakarta. Penulis merupakan Dosen Tetap Prodi Isipol Universitas Proklamasi 45 Yogyakarta.

\section{Drs. Edy Rismiyanto, M.M.}

Penulis lahir di Solok Sumatera Barat, 29 februari 1960 adalah dosen tetap dengan pangkat lektor di prodi managemen Universitas Proklamasi 45 yogyakarta. Lulus S1 Fakultas Ekonomi UP 45 tahun 1988, dan menyelesaikan S2 dari STIE MTRA INDONESIA tahun 2004. Pernah menjabat berbagai jabatan struktural, seperti kepala Biro Administrasi Akademik, Ketua Jurusan Manajemen dan pernah menjadi Wakil Rektor III bidang kemahasiswaan. Penelitian, baik penelitian mandiri maupun penelitian yang di danai oleh Kopertis, Dikti, dan instansi pemerintah. Minat kajiannya adalah di bidang manajemen pemasaran dan manajemen strategik. Beberapa hasil karyanya telah di publikasikan melalui berbagai jurnal.

\section{Dra. Eny Sulistyowati, M.M.}

Penulis lahir di Magetan, 1 Januari 1965. Menyelesaikan studi S1 pada Fakultas Ekonomi Jurusan Manajemen Universitas Proklamasi 45 Yogyakarta, dan S2 pada Program Magister Manajemen STIE Mitra Indonesia. Saat ini penulis menjabat sebagai Ketua Program Studi Manajemen pada Fakultas Ekonomi Universitas Proklamasi 45 Yogyakarta. Selain mengajar juga aktif di beberapa penelitian dan menjadi traineer pelatihan.

\section{Dona Primasari, S.E., M.S.c.}

Penulis lahir di Palembang, 5 September 1981. Menyelesaikan pendidikan S1 di Universitas Sriwijaya Palembang dan S2 di Universitas Diponegoro Semarang, sekarang sedang proses S3 di Universitas Diponegoro Semarang. Penulis adalah dosen Fakultas Ekonomi dan Bisnis Universitas Jenderal Soedirman. 


\section{Heriyanto, S.E.}

Penulis lahir di Pati, pada tanggal 15 Juli 1989. Penulis adalah Alumni Fakultas Ekonomi Universitas Proklamasi 45 Yogyakarta T.A. 2015/2016 dengan predikat kelulusan Sangat Memuaskan.

\section{Drs. Jemadi, M.M.}

Penulis lahir di Kulon Progo, 20 September 1963. Lulus S1 di Fakultas Ekonomi Universitas Proklamasi 45 Yogyakarta pada tahun 1989 dan menyelesaikan S2 di STIE Mitra Indonesia pada tahun 1999. Beliau pernah menjabat berbagai jabatan Struktural, seperti Ketua Jurusan Manajemen.

\section{Dra. Nining Sofiati Lestari, M.Sc.}

Penulis lahir di Yogyakarta, 26 Maret 1955. Menyelesaikan S1 dan S2 dari Universitas Gadjah Mada Yogyakarta. Penulis berstatus sebagai dosen tetap Yayasan di Fakultas Ilmu Politik Universitas Proklamasi 45 Yogyakarta. Beberapa karya ilmiah baik hasil pengabdian masyarakat maupun hasil penelitiannya telah diterbitkan pada Jurnal Ilmiah. Mata kuliah yang diampu adalah Sejarah Pergerakan Nasional, AMDAS, Sosiologi Indonesia.

\section{Dra. Siti Noor Hidayati, M.M.}

Penulis adalah dosen tetap di Fakultas Ekonomi Universitas Proklamasi 45. Penulis tamat dari Jurusan Umum, Fakultas Ekonomi Universitas Gadjah Mada tahun 1980, dan menyelesaikan pendidikan pasca sarjana di program Magister Manajemen Universitas Islam Indonesia tahun 2001. Bidang kajian yang ditekuninya adalah manajemen sumber daya manusia dan ekonomi kuantitatif. Penulis telah menulis beberapa buku teks mengenai ekonomi mikro dan metode kuantitatif.

\section{Susi Widjajani, S.E, M.Si.}

Penulis lahir di Magelang, 22 September 1971. Menyelesaikan studi S1 pada fakultas Ekonomi Jurusan Manajemen Universitas Proklamasi 45 Yogyakarta dan lulus dengan predikat cumlaude. Selanjutnya menyelesaikan studi S2 pada Program Magister Sains Fakultas Ekonomi \& Bisnis Universitas Gadjah Mada Yogyakarta dengan konsentrasi Manajemen Sumber Daya Manusia. Selain menjadi dosen pada Fakultas Ekonomi Universitas Proklamasi 45 Yogyakarta, juga aktif sebagai peneliti yang konsisten dengan bidang Manajemen Sumber Daya Manusia. Telah mempublikasikan banyak artikel hasil penelitian pada berbagai jurnal ilmiah. Selama ini juga aktif sebagai tenaga ahli pada berbagai pekerjaan baik Instansi Pemerintah Pusat maupun Pemerintah Daerah.

\section{Siwi Susanti, S.E.}

Penulis lahir di Surakarta pada tanggal 26 Mei 1972. Penulis adalah Alumni Fakultas Ekonomi Universitas Proklamasi 45 Yogyakarta T.A. 2015/2016 dengan predikat kelulusan Cumlaude. 


\section{MITRA BEBESTARI}

Ucapan terimakasih dan penghargaan yang setinggi-tingginya diberikan kepada para mitra bebestari yang telah menjadi penelaah bagi Jurnal Maksipreneur Volume VI Nomor 1, Desember 2016. Berikut adalah daftar mitra bebestari yang telah berpartisipasi:

Prof. Dr. M. Dawam Rahardjo, S.E. (Universitas Proklamasi 45), untuk telaah ekonomi dan koperasi

Prof. Dr. R. Andi Soelarso, S.E., M.Si. (Universitas Jember), untuk telaah ekonomi dan manajemen

Prof. Dr. Kustim Wibowo, M.Sc. (Indiana University of Pennsylvania), untuk telaah sistem dan teknologi informasi

Dr. Rezki Anindhito, M.Sc. (Universitas Bina Nusantara), untuk telaah ekonomi, energi dan keuangan

Dr. H. Slamet Sutrisno, M.M., M.Si. (Universitas Krisnadwipayana), untuk telaah ekonomi manajemen dan kewirausahaan

Dr. Wing Wahyu Winarno, MAFIS., Ak, CA. (STIE YKPN Yogyakarta), untuk telaah sistem informasi manajemen 


\section{KEBIJAKAN EDITORIAL DAN PEDOMAN PENULISAN ARTIKEL JURNAL MAKSIPRENEUR}

\section{Kebijakan Editorial}

1. Jurnal diterbitkan 2 (dua) kali dalam satu tahun oleh Fakultas Ekonomi Universitas Proklamasi 45 Yogyakarta pada bulan Juni dan Desember.

2. Jurnal menerima artikel hasil penelitian maupun non penelitian yang mengkaji permasalahan manajemen, koperasi, kewirausahaan, dan ekonomi secara umum.

3. Naskah artikel bisa ditulis dalam bahasa Indonesia dan Bahasa Inggris dengan memperhatikan kaidah kebahasaan yang baik dan benar.

4. Naskah adalah hasil karya penulis yang belum pernah dipublikasikan di media lain.

5. Penentuan kelayakan artikel yang dimuat melalui proses blind review oleh Penyunting Pelaksana. Artikel yang tidak layak untuk dimuat tidak dikembalikan, kecuali atas permintaan penulis.

6. Pengiriman naskah untuk dimuat paling lambat 1 bulan sebelum diterbitkan untuk setiap edisi. Keterlambatan penerimaan naskah akan diterbitkan pada periode berikutnya.

\section{Pedoman Penulisan Artikel}

1. Sistematika penulisan:

a. Judul, ditulis secara ringkas dan jelas dengan panjang judul tidak lebih dari 12 kata atau 90 karakter.

b. Nama penulis, dicantumkan di bawah judul. Di bawah nama penulis dicantumkan unit kerja atau instansi beserta alamat email.

c. Abstract, ditulis dalam bahasa Inggris dan bahasa Indonesia dalam satu paragraph tidak lebih dari 200 kata yang berisi intisari tulisan dan ide-ide pokok tulisan.

d. Keywords, terdiri atas sekitar lima kata kunci yang dipisahkan dengan koma.

e. Isi Tulisan/Naskah, mencakup: pendahuluan, kerangka teoritis, metode penelitian, hasil penelitian, pembahasan, serta simpulan, implikasi dan saran. Tulisan bisa dilengkapi dengan tabel, gambar, dan ilustrasi lainnya jika diperlukan.

f. Ucapan terima kasih atau penghargaan (acknowledgement), jika diperlukan.

g. Daftar Pustaka

2. Naskah diketik menggunakan microsoft word dengan ketentuan sebagai berikut: ukuran kertas A4, spasi 1,5, huruf (font) Time News Roman (12 poin), naskah diserahkan dalam bentuk softcopy berikut 2 (dua) eksemplar hardcopy.

3. Jumlah halaman naskah, termasuk tabel, gambar, dan ilustrasi lain 15 sampai 20 halaman kwarto.

4. Ketentuan Lain:

a. Judul tabel, gambar, dan ilustrasi lain diberi nomor dan diletakkan rata tengah. Judul tabel diletakkan di atas, judul gambar dan ilustrasi lain diletakkan di bawah.

b. Jika tabel, gambar, atau ilustrasi lain merupakan kutipan, sumber kutipan disebutkan di bawahnya. 
c. Kutipan dalam bentuk teks sebaiknya ditulis dengan menyebutkan nama akhir penulis, tahun, nomor halaman (jika dipandang perlu).

Contoh:

-(Kotler, 2009,143)

-Kotler $(2009,143)$ mengatakan bahwa

d. Daftar pustaka disusun secara alfabetis yang berisi nama penulis (nama belakang ditulis lebih dahulu, dan dipisah dengan tanda koma), diikuti tahun publikasi, judul artikel atau buku teks, nama jurnal atau penerbit tahun publikasi, judul artikel atau buku teks, nama jurnal atau penerbit, edisi, kota.

Contoh penulisan daftar pustaka:

$\square$ Yustika, Ahmad Erani. 2003. Negara versus Kaum Miskin.

Yogyakarta: Pustaka Pelajar.

$\square$ Wahono, Francis, 2008, "Kedaulatan Pangan: Agri-culture bukan Agri-business", dalam Suharman (Ed.), Bunga Rampai Pemikiran Pedesaan, 2002-2008 (Yogyakarta: Pusat Studi Pedesaan dan Kawasan [PSPK] UGM, 2008).

$\square$ Donohue, John J. dan Steven D. Levitt, 2004, “The Impact of Legalized Abortion on Crime" dimuat dalam The Quarterly Journal of Economics, Vol. CXVI, May 2001, hal. 379-420. 